\title{
A Comparative Study of e-Writing and Traditional Writing Classroom to Improve English Writing Ability and Motivate Autonomous Learning of Thai EFL Learners
}

\author{
Pongpatchara Kawinkoonlasate, Ph.D. \\ English Department \\ Faculty of Liberal Arts \\ HuachiewChalermprakiet University \\ SamutPrakarn, Thailand
}

\begin{abstract}
The purposes of this quasi-experimental study were: 1) to compare students' writing ability before and after receiving $e$-Writing program and traditional writing classroom., 2) to compare the differences in learner satisfaction and motivation after receiving e-Writing and traditional writing classroom., and 3) to explore learner autonomy after receiving the two different kinds of teaching methods. The informants were 60-second year students who were divided by quota sampling method into two groups (A and B) of 30 learners each. Group A received an e-Writing method, whereas Group B received a Traditional writing classroom. The research instruments used for data collection were lesson plans, e-Writing program, learner perception questionnaires, interview questions, and English writing test (Pretest and Posttest). The quantitative data were collected and analyzed using average, standard deviation, and t-test. Interview data was analyzed by means of content analysis.

The quantitative finding revealed that the English writing ability of the students group under e-Writing teaching was significantly higher than the controlling group at the .001 level. From the questionnaire results, the overall levels of satisfaction and autonomous learning after receiving the e-Writing program were found to be good. Additionally, the interview results showed that the students seemed to enjoy the lessons more in the e-Writing which appeared to promote more learner autonomy than the traditional writing classroom. Recommendations were made and presented in two categories: benefits of future practice and further research.
\end{abstract}

Keywords:e-Writing, Traditional Writing Classroom, English Writing, Autonomous Learning

\section{Introduction}

As global era communication expands throughout the world, the modern technology innovated very quickly and lifestyle of the city people has changed very much. Most of the people around the world use technology all the time. They can very easily use the internet to share new update knowledge and to communicate with freedom through the social network. In terms of education, studying English and applying electronic devices are important for all learners. In this issue, technology also provides support and conditions by increasing freedom of choice, flexibility in scheduling, authentic materials, and electronic communication. Technological wizardry and innovation may lead the teacher to forget the basic pedagogical principles, which underlie autonomous language teaching (AbuSeileek\&Abualsha'r, 2014). In English as a second language (ESL) and English as foreign language (EFL) students, it is necessary that teachers have to access to a variety of methods which give opportunities for learners to practice and develop their English skills.

Writing skills are one of the most important skills and often linked to other skills, thereby lessening the valuable role. Writing is perceived to be the hardest skill to acquire; it is becoming more demanding in the age of entire communication via email and other communicative technologies, also. It is important for educators to motivate their students to write by showing them appropriate strategies so that they will be successful in writing. Teachers of basic writing need to give many different kinds of writing assignments in order to discover their students' strengths and weaknesses and the Internet has many tools to help in this determination (Stine, 2010).This might improve student' skills to enable all students to write; a student who does not originally have talent and superior skills can still become a successful author.

However, the problems in teaching and learning English as a foreign language (EFL) and English as a second language (ESL) are related to both students and teachers. Some of these problems are concerned with teaching methodologies (Kannan, 2009). Most EFL teachers teach language by lecturing and focusing on grammatical rules instead of communicative language. 
To solve these problems, Albalawi (2015) has mentioned that there are many teaching delivery methods such as virtual classes and blended as well as traditional face-to-face classes. Gregoriades, Pampaka, and Michail (2009) indicated teachers should select an effective teaching delivery method to teach the students as understanding students' learning style assists teachers to adapt their teaching method to better support the student learning and using a suitable teaching delivery method leads to meaningful learning.Therefore, the way to improving students' English writing skills might provide suitable teaching delivery methods and modern teaching media to stimulate their desire for interacting in the target language and to create multiple opportunities for students to practice.

This study aims to separate methods, which could help to improve learners' writing ability through the use of the eWriting program. Therefore, the following objectives are set:To compare students' writing ability through e-Writing classroom and traditional writing classroom, to compare the effectiveness of e-Writing classroom and traditional writing classroom, and to explore learner autonomy after receiving the two different kinds of teaching methods. The central research questions for this study are: 1. Are there any differences in students' e-Writing classroom and traditional writing classroom?, 2. What are the effects of e-Writing and traditional writing methods on student satisfaction and motivation?, and 3. How do the two different teaching methods promote autonomous learning?

\section{Conceptual Framework}

Independent Variable

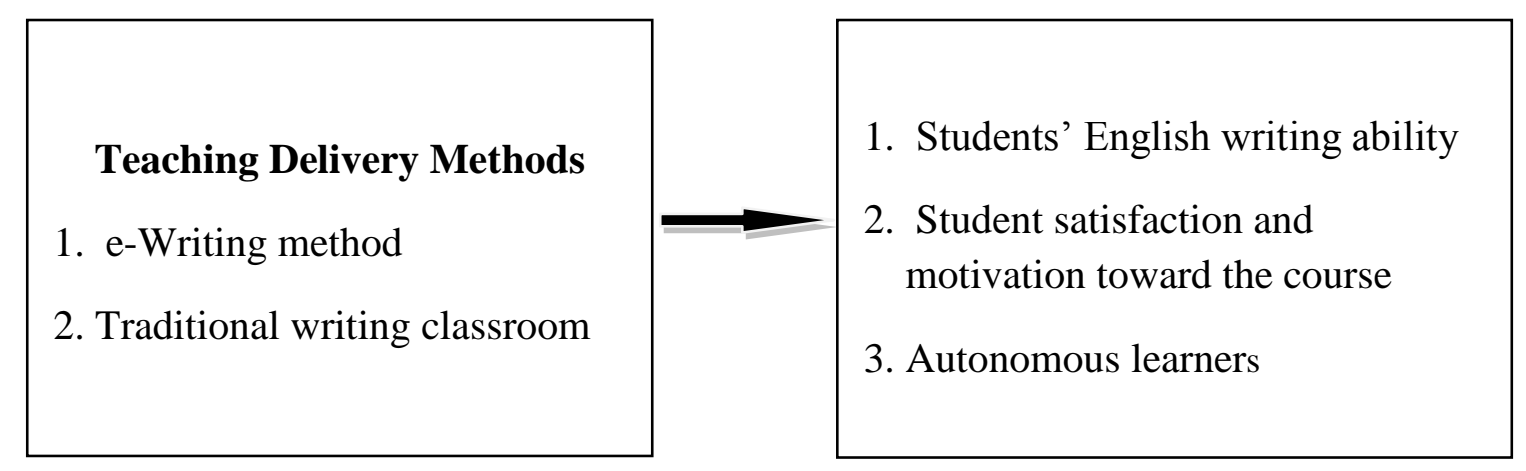

Figure 1-1 Conceptual framework of this study

According to this conceptual framework, the independent variable in this study is the teaching delivery methods, which consist of e-Writing instructional design program, and traditional teaching method. A comparative study between two teaching delivery methods, which hope to find out that one teaching delivery method, might be effective for students' English writing ability, their satisfaction, and autonomous learner. The dependent variable in this study depends on students' English writing ability, student satisfaction and motivation toward the course, and autonomous learners.

\section{Literature Review}

\subsection{The Importance of English Writing Ability and Effective Writing}

Writing is an important communication format to express one's ideas and needs. When children become adolescents, writing skills seem more important in their daily lives to communicate with others as a formal means. Effective writing skills are necessary for students when graduating from an educational organization, also. Moreover, English writing provides a means for students to precede new information in their own words. It is particularly effective in large classrooms where breaking students into pairs or groups may be prohibitive. It also appeals to an individual who prefer to learn independently. Writing is claimed by a number of scholars/linguists (Sawalmeh, 2013) as one of the most important skills in learning English. Furthermore, regarding English writing contexts, they are generally divided into English as a second language (ESL) and English as foreign language (EFL) contexts. The difference between these two contexts is that ESL contexts are those in which the English language is normally used in everyday life activities and in local communities. Similarly, Chappell (2011) mentions that writing is an essential job skill, which helps the learner, understand how truth is established in a given discipline. It also fosters the writer's ability to explain a complex position to readers clearly. Writing to learn, supportive and encouraging teachers in $21^{\text {st }}$ century education systems and the effective use of technology will improve the writing and learning process for every grade level of student, no matter their background or experience. Panah, Yunus, and Embi (2013) point out that using Google or other electronic devices for word searches is an effective tool for students who are learning another language or who are given writing tasks; research has shown that it is both motivating and effective as a learning tool. 
At the same time, Hussein (2011) confirms that collaborative technology in the classroom has facilitated in helping students to be personally responsible for their own learning and provides them with the ability to vary their creativity as they choose. Applying technology in educational instruction assists students to improve not only English writing skills but also vocabulary skills. In terms of students' vocabulary skills, they are improved with the use of the Internet and when combined with instruction and motivational e-Writing tools, technology supports and heightens learning by stimulating creativity and a thirst for details. Along with proper mentoring and instruction, students are encouraged to find information, plan and organize their opinion, imagine and then develop a paper that will be interesting and shared with the rest of the class. Hence, writing becomes a fun assignment instead of a hardship.

\section{2 e-Writing Strategies Instruction and English Language Learning Motivation}

Technological language learning is one method for encouraging students to learn both inside and outside the classroom. Using unusual and exciting activities instead of textbooks can motivate learners to study the English language.Scott and Mouza (2007) mentions that writing skills are critical no matter what age level one may be. There have been numerous amounts of studies that show students have an easier time expressing themselves when they are able to write their thoughts and feelings down on the computer. By having the ability to access and utilize Wikis, e-Writing, Blogs, and chats allow students to express their feelings without having to be apprehensive about what others may think or say aloud in class. Having these resources for our students increases their abilities to write meaningful text. Furthermore, technology is a powerful tool in education and in most cases increases writing skills. David, Keaton, Morris, Murphy, and Stapley (2008) claim that instructional needs must drive the arrangement of technology.

Motivation in education effects on how students learn and how they behave towards a subject matter. It can direct behavior toward particular goals, lead to increased effort and energy. Educational psychologists have long recognized the importance of motivation for supporting student learning. Prakash (2007) reports that motivation is the heart of significant age level. When motivation is high, students learn things without taking much time, but when it is low, they take a longer time to learn the writing skill aspects and they are exposed to make many errors in learning the material. In addition, learning attitudes are important predictors of achievement. Learner autonomy in this study is often defined as learners' ability to take control of their own learning and it has become a key concern in the foreign language or second language instruction context in recent decades due to the change from traditional classroom settings which students are passive learner learner-centered approaches. Autonomous learners are more active and efficient in the process of language learning and autonomous learners are more motivated to take part in various activities for learners (Zarei\&Gahremani, 2010). The development of learner autonomy is widely varied depending on teachers' roles and overall classroom environment.Consequently, teachers should provide various ways to apply technology in language classrooms to promote learner autonomy and efficient learning outcomes.

\subsection{Traditional Writing Teaching Method}

Teaching styles have changed significantly over the years. The traditional way that education was delivered through recitation and memorization techniques, whereas the modern way of doing things involves interactive methods. Traditional learning also as a single path helps learners identify a clear direction and goal, thus a learner has a lower chance of getting lost or having trouble (Martin, 2008). In addition, the traditional approach is mostly teacher-centered, occurs frequently with the whole class, teacher talk exceeds student talk, and use of class time is largely determined by the teacher. Furthermore, Qian (2010) pointed out that the most influential approach of the traditional methods of organizing language teaching is that of the 3Ps: presentation, practice, and production. The first step is generally focused on a single point of grammar, which is presented explicitly to maximize the chances that the underlying rule will be understood and internalized which is the development of declarative knowledge. This initial stage would be followed by practice activities and to convert declarative to procedural knowledge. For the production stage, the learners would want to express their knowledge with themselves to produce their tasks.

However, in the present English teaching, the importance of writing is always being neglected, and then writing becomes a weak link in English teaching and learning. Although, most of the teachers adopt the traditional teaching method, "teacher-centered" model. Learners are able to receive certain knowledge of English writing under the guide of traditional teaching approach, they haven't understood the key of writing (He, 2015). Many students are able to understand the language, but most of the students face the problem of communicating their ideas effectively. The problems were the lack of both the inadequate stock of English vocabulary and creativity in writing. It is evident that writing is the biggest challenge for many students (Adas\&Bakir, 2013).Traditional teaching is humanistic; teachers stand in as a moderator and handle interactions to maximize learning and this improves communication skills. Traditional teaching mode is single. In the teaching process, the teacher is the center, and the teaching process emphasizes system and completion but few thinking spaces for students. 
In contrast, Traditional teaching can easily be boring for learners because there is not enough time or power to teach, also. In this point, Writer Staff (2011) pointed out that the traditional teaching method might not be the right fit for every course and it did not encourage the students in all learning styles. Teachers were more emphasis on examinations and results rather than an understanding of concepts, and they were in the mode of knowledge dispensers rather than facilitators (Nazzal, 2014). At the same time, Kelly (2018) still insisted that traditional teaching method was a timetested instructional method where an instructor who possesses the knowledge on a given topic delivers all relevant information to students verbally as well. In a nutshell, the traditional teaching method had some advantages and the teaching methods are simple and convenient for teachers to manage the classroom teaching and learning.

\section{Research Methodology}

\subsection{Research Design}

This study aims to compare the student achievement of English language learning using e-Writing and traditional teaching methods for students who study in Basic English Writing course and to enhance the English writing ability and motivate autonomous learning of students. In this study, the researcher designs a model for the e-Writing instructional design program. The researcher divided this study into two sections. The first section of e-Writing instructional design program is extra content concerning writing strategies. The second section is four kinds of paragraph writing with assignments. The research instruments in this study consisted of lesson plans, model for an eWriting instructional design program; lessons on writing strategies and four kinds of writing paragraph topic with assignments, learners' perception questionnaire, interview questions, and writing test (Pretest and posttest).The participants in this study were the students who enroll in Basic Writing in English course. The participants are divided by quota sampling method into two groups of 30 learners, the experimental group A (e-Writing), and group B the control group (Traditional Writing Classroom).

\subsection{Data Collection}

This study is taught and conducted by the researcher for 15 weeks with a total of 15 sessions in the first semester of the academic year 2018. This research was carried out from August 2018 to December 2018. The whole inquiry was an on-going process with data collection and analysis paralleling overlapping each other. Therefore, the researcher collects the data using the following procedure. The researcher asks HCU's permission to conduct the study. The scores from this study do not affect the students' grade for each group. After permission was granted, the participants were divided into three groups as follows:

1. The experimental group A (e-writing): 45 hours in total (3 hours per week): The experimental group received the lesson on reading comprehension strategies and doing the e-writing with assignments.

2. The control group B (Traditional writing teaching): 45 hours in total ( 3 hours per week): The controlled group studied through traditional writing teaching method focusing on a textbook and worksheets.

\subsection{Data Analysis}

The data obtained from different methods were analyzed and interpreted in two main ways: quantitative and qualitative data analysis. The following statistical analysis was used in this study by the mean $(\overline{\mathbf{x}})$ and standard deviation (SD). The scores on the pre and posttest were computed and converted into mean scores and dependent t-test. The steps of the data analysis process involved determining the mean and standard deviation of each group to check whether or not the mean scores of the pre and post tests are significantly different.Interview questions, the data were read, reread, and then coded. Coding organized the raw data into meaningful categories.

\section{Results}

In this study, the results would be presented into two sections. The first section would be presented as quantitative data report and the final section would be presented as qualitative data report.

\subsection{The quantitative data report would be presented as the following section.}

The students' ability of writing before and after receiving e-Writing and traditional writing classroom was different. According to the achievement results, the pretest scores and the posttest scores of each group (A and B) were different. The Pre-test scores (30 points) of group A had statistical significance at the 0.001 level. The posttest scores ( 30 points) of the students after receiving their teaching delivery method (e-Writing) were higher than the pretest scores. The mean scores of the pretest of Group A (e-Learning) were at 13.93 and the standard deviation was at 3.028. Whereas, the mean scores of the posttest of Group A (e-Learning) were at 21.10 and the standard deviation was at 0.885 . The posttest scores of students in each group were not similar. The posttest scores of the control group students after receiving their teaching delivery method were higher than the pretest scores. The mean scores of the pretest of Group B (Traditional Writing Classroom) were at 13.93 and the standard deviation was at 2.164. 
Whereas, the mean scores of the pretest of Group B (Traditional Writing Classroom) were at 16.07 and the standard deviation was at 1.911. This meant that the teaching delivery method using e-Writing assisted students to significantly improve their English writing ability. When the relationship among groups of students and the different levels of the pre-test and post-test scores were analyzed, the findings show that the students in each group (A and B) had higher posttest scores after they studied with the teaching delivery method that they received.

In addition, the different level scores of six exercises between Group A and B would be presented as the following.

Table 1 The Different Level Scores of Exercises No. 1 between Group A and B

\begin{tabular}{l|c|c|c|c|c}
\hline Students'Group & $\mathbf{N}$ & $\overline{\mathbf{x}}$ & $\mathbf{S D}$. & $\mathbf{t}$ & $\mathbf{S i g}$ \\
\hline Group A (e-Writing) & 30 & 17.57 & 3.266 & 7.658 & $.000^{* *}$ \\
GroupB (Traditional Writing Classroom) & 30 & 13.00 & .000 & & \\
\hline
\end{tabular}

** Level of statistical significance .001

* Level of statistical significance .05

From table 1, Exercise No. 1 had 30 points. The total average scores Of student group A (e-Writing) were at 17.57 and Group B (Traditional Teaching Method) was at 13.00 respectively. The different scores of both groups of students were compared; it showed that the achievement result of students in group A (e-Writing) was higher than the students of group B (Traditional Writing Classroom), and there was statistical significance at the .001 level.

Table 2 The Different Level Scores of Exercises No. 2 between Group A and B

\begin{tabular}{l|c|c|c|c|c}
\hline Students'Group & $\mathbf{N}$ & $\overline{\mathbf{x}}$ & $\mathbf{S D}$. & $\mathbf{t}$ & Sig \\
\hline Group A (e-Writing) & 30 & 18.47 & 3.048 & -.331 & $.048^{*}$ \\
GroupB (Traditional Writing Classroom) & 30 & 18.70 & 2.366 & & \\
\hline
\end{tabular}

** Level of statistical significance .001

* Level of statistical significance .05

According to the table 2, Exercise No. 2 had 30 points. The total average scores Of student group A (e-Writing) were at 18.47 and Group B (Traditional Writing Classroom) was at 18.70. The different scores of both groups of students were compared, it found that the achievement result of students in group A (e-Writing) was lower than the students of group B (Traditional Writing Classroom), and there was statistical significance at the .05 level.

Table 3 The Different Level Scores of Exercises No. 3 between Group A and B

\begin{tabular}{l|c|c|c|c|c}
\hline Students'Group & $\mathbf{N}$ & $\overline{\mathbf{x}}$ & SD. & $\mathbf{t}$ & Sig \\
\hline Group A (e-Writing) & 30 & 23.00 & 4.379 & 8.756 & $.000^{* *}$ \\
GroupB (Traditional Writing Classroom) & 30 & 16.00 & .000 & & \\
\hline
\end{tabular}

** Level of statistical significance .001

* Level of statistical significance .05

According to the table 3, Exercise No. 3 had 30 points. The total average scores Of student group A (e-Writing) were at 23.00 and Group B (Traditional Writing Classroom) was at 16.00 respectively. The different scores of both groups of students were compared, it found that the achievement result of students in group A (e-Writing) was higher than the students of group B (Traditional Writing Classroom), and there was statistical significance at the .001 level.

Table 4 The Different Level Scores of Exercises No. 4 between Group A and B

\begin{tabular}{l|c|c|c|c|c}
\hline Students'Group & $\mathbf{N}$ & $\overline{\mathbf{x}}$ & SD. & $\mathbf{t}$ & Sig \\
\hline Group A (e-Writing) & 30 & 21.40 & 3.114 & 5.980 & $.000^{* *}$ \\
GroupB (Traditional Writing Classroom) & 30 & 18.00 & .000 & & \\
\hline
\end{tabular}

*** Level of statistical significance .001

* Level of statistical significance .05

Table 4 showed that Exercise No. 4 had 30 points. The total average scores 0f student group A (e-Writing) were at 21.40 and Group B (Traditional Writing Classroom) was at 18.00 respectively. The different scores of both groups of students were compared, it found that the achievement result of students in group A (e-Writing) was higher than the students of group B (Traditional Writing Classroom), and there was statistical significance at the .001 level. 
Table 5 The Different Level Scores of Exercises No. 5 between Group A and B

\begin{tabular}{l|c|c|c|c|c}
\hline Students'Group & $\mathbf{N}$ & $\overline{\mathbf{x}}$ & $\mathbf{S D .}$ & $\mathbf{t}$ & Sig \\
\hline Group A (e-Writing) & 30 & 21.80 & 2.683 & .477 & .295 \\
GroupB (Traditional Writing Classroom) & 30 & 21.50 & 2.162 & & \\
\hline
\end{tabular}

** Level of statistical significance .001

* Level of statistical significance .05

From table 5, Exercise No. 5 had 30 points. The total average scores 0f student group A (e-Writing) were at 21.80 and Group B (Traditional Writing Classroom) was at 21.50. The different scores of both groups of students were compared, it found that the achievement result of students in group A (e-Writing) was higher than the students of group B (Traditional Writing Classroom), and there was not statistical significance at the .05 level.

Table 6 The Different Level Scores of Exercises No. 6 between Group A and B

\begin{tabular}{l|c|c|c|c|c}
\hline Students'Group & $\mathbf{N}$ & $\overline{\mathbf{x}}$ & SD. & $\mathbf{t}$ & Sig \\
\hline Group A (e-Writing) & 30 & 23.40 & .976 & 6.355 & .144 \\
GroupB (Traditional Writing Classroom) & 30 & 19.57 & 2.648 & & \\
\hline
\end{tabular}

** Level of statistical significance .001

* Level of statistical significance .05

From table 6, Exercise No. 6 had 30 points. The total average scores 0f student group A (e-Writing) were at 23.40 and Group B (Traditional Writing Classroom) was at 19.57. The different scores of both groups of students were compared, it found that the achievement result of students in group A (e-Writing) was higher than the students of group B (Traditional Writing Classroom), and there was not statistical significance at the .05 level.

Next, the comparison of differences between groups of students toward the level of student satisfaction with their teaching method. This study found that a group of students toward a level of satisfaction for this course had different mean scores in each item. The overall level of learners' satisfaction after they have received their teaching method was at a "good" satisfaction level, 3.81. The mean scores of students' satisfaction in the group A (e-Writing) were at 4.41 and the standard deviation was at .496 whereas the mean scores of students' satisfaction in group B (Traditional Writing Classroom) were at 3.22, and the standard deviation was at .560.To sum up, those students in Group A (eWriting) were satisfied studying with the e-Writing program more than a traditional teaching method. The level of students' satisfaction of Group A (e-Writing) presented that the students preferred to study and practice their writing skill via e-Writing program more than to study with traditional writing classroom.In addition, the students' autonomous learning of two groups toward the two teaching delivery methods was at "good" level, 3.46.Thestudents in Group A (eWriting) have developed more autonomous learning than students in Group B (Traditional Teaching Method). The mean scores of students' autonomous learning in Group A (e-Learning) was at 4.43, Group B (Traditional teaching) was at 2.49 .

\subsection{The qualitative data report would be presented as the following section.}

The qualitative data was divided into two sections. The first section would be the students' satisfaction including the category of learning experience, the category of satisfaction, and the category of suggestion and the second section would be the students' autonomous learning including the category of learning experience, the category of satisfaction, and the category of suggestion as well.In the first category, participants in group A have improved their English writing skill and realized writing processes. They emphasized on applying technology in educational instruction and it was convenient to use this kind of technology in classroom. In addition, the students had responsibility for their study. Whereas, the participants' attitudes in group B toward their teaching method were not satisfied. They expressed negatively with the traditional teaching method. First, they claimed that their English writing skill was less improved. The participants would like to get more learning experience from this course, indeed. Then the participants expressed that they got less knowledge for learning in this course. Finally, this teaching method did not provide the participants with a learning experience and atmosphere.

The category of satisfaction, participants in group A expressed positive, and satisfaction toward the e-Writing program. Participants expressed different satisfaction in terms of the benefit of this program, the appropriate program for learning, and the learning atmosphere. During their learning, they felt relaxed because there was no time limitation to study. They felt free to study both inside and outside the classroom. They also had meditation as well. 
Meanwhile, the participants in group B expressed that this teaching method might be uninteresting for learning. The participants expressed their attitude toward this teaching method that they were not satisfied with it. This teaching method might not be suitable for their learning.

The category of recommendation, the participants' opinion, they would like all subjects to design the learning material using technology or e-Learning program. Due to this program, they could learn as much as they wanted and they could practice their lessons without time limitation. This program was quite challenging and motivating for all learners to learn rather than learning with regular classroom. Based on the suggestions of an e-Writing program, participants illustrated and suggested for further development such as in terms of contents that should have more details and contents with writing assignments. In contrast, the participants from group B stated that one point that different from other. They suggested that the teacher should change the teaching delivery method instead of the traditional one.

For the results from the interview question toward student's autonomous learning, the results from the interview questions of the student groups (A and B) presented a different point of view. At first, the category of the learning experience, the students from groups A was positive toward the teaching delivery method that they received. They mentioned that studying with e-Writing supported their student-centered learning and they were able to practice their responsibility, punctuality, and motivation. Moreover, the participants practiced their study by themselves and this point allowed them to become autonomous learners. However, the students of group B expressed negatively with their teaching delivery method. They stated that the traditional teaching method did not provide learning experience because it focused on teacher center. They might not be interested in learning with it, so they could not create their own learning atmosphere. For the category of satisfaction, the students from group A mentioned positively. They claimed that the learning environment or learning atmosphere of an e-Writing program was fun and relaxed. They were satisfied with their teaching delivery method that they received in terms of a relaxed learning atmosphere. Whereas the students from group B expressed negatively toward their teaching delivery method, they were dissatisfied with it.

\section{Discussion}

According to research question 1, the two delivery methods of teaching (e-Writing and Traditional Writing Classroom) impacted students' English writing ability.The teaching delivery method in Group A (e-Writing) was effective for students to study. The writing achievement level of the students in Group A before and after receiving the treatment was significantly different at 0.001. The result was congruent with the study of Santoso (2010) who studied the use of technology tools such as word processing, computer-writing systems, and computer-assisted writing software increased the quantity and quality of student writing more than traditional instructional methods. The students have known for how to apply the writing strategies in their writing after their study that the same point of Ridha (2012) that writing was a tool for students by stretching their knowledge and connect to the topic. Furthermore, to encourage the students' learning atmosphere, Kelley (2008) insisted that applying technology would enhance learning, motivate students, and allow them to develop writing skills. Geluso (2013) asserted that the students were able to improve their writing skills via Google sited. To support this study result, Hussein (2011) claimed that collaborative technology in the classroom has facilitated students to be personally responsible for their own learning and provides them the ability to vary their creativity as they choose.

However, traditional teaching method might not motivate every learning style for the students in this course. According to Lui and Long (2014), the problems of traditional teaching method happened when it put teachers at the center all the time, mainly depending on class knowledge, which emphasizes the role of teachers too much. Because of these reasons, the students might have some problems to cope with how their lessons were delivered.

According to research question 2, the students in group A (e-Writing) were satisfied with their teaching method and the mean scores were at 4.41 while the students in group B (Traditional Writing Classroom) were satisfied with their teaching method with the mean scores at 3.22.Gditawi, Noah, \& Abdul Ghani (2011) insisted that students' motivation affected on their learning. Moreover, the students had freedom because they were able to study by themselves anywhere and anytime. This was congruent with the results of previous studies (Godwin-Jones, 2009; Ramaswami 2009; Wilson \& Allen, 2010). Technology like e-Writing program provides different opportunities to make learning more fun and enjoyable in terms of teaching in new ways. e-Writer enabled students to learn at their own pace. The students were able to learn according to their abilities and needs.For the traditional writing classroom, Most of the students hardly satisfied with the teaching that they received.Lui, \& Long (2014) and Selinger (2008) confirmed that the problems of traditional teaching method were passive learning. The findings from interview of each group (A and B) were discussed in each category as follows:

1. Category of Learning Experience after the students in group A (e-Writing) learned with the e-Writing program,the participants from Group A (e-Writing) expressed a positive attitude toward their teaching delivery method.The students have known how to practice their writing in each step and write effectively and accurately.

32 
They were also able to gather all the information and write well which was congruent with the study of Sarfraz (2011) and Baker (2011).e-Writing helped them to become autonomous learners. This issue Zarei\&Gahremani (2010) confirmed that autonomous learners were more active and efficient in the process of language learning. While the participants from Group B (Traditional Writing Classroom) showed negatively that they were dissatisfied with traditional teaching.

2. Category of Satisfaction,Group A (e-Writing) felt satisfied with their teaching delivery method.The study of Gditawi, Noah, \& Abdul Ghani (2011) had the same result that motivation was one of the important factors for the students to reach their learning objective.The participants from Group B felt negatively toward their teaching delivery method, it was not suitable for them to study for the undergraduate level.

3.Category of Recommendations, the participants in group A recommended the need for further development in terms of adding more video clip and sound in the program. From the study of Douglas, Ayres, Langone, Bramlett (2011) applying modern technology might be useful to encourage the students' instruction. The participants in group B suggested and emphasized technology. Traditional teaching method was an old way to teach. Nowadays, technology in education was better than teaching with paper.

\section{Recommendations of the study}

The researcher expected the recommendations for future practice might assist instructors to teach and design the learning media effectively. Also, the researcher expected that the category of research recommendations might encourage other researchers to continue to study this field in order to design more effective learning media. These practical recommendations to inform instructors how to better adjust the teaching delivery methods in order to address the needs of the students.

\section{Conclusions}

Modern electronic educational technology was an important factor in society.Technological education like e-Writing in this study was an inclusive term for both the material tools and the theoretical foundations for supporting learning and teaching in terms of pedagogical resources and connecting with the younger generations. In the light of the results of this study, newinnovations, especially regarding technology, did not replace traditional approaches, but enhance them, and motivate international students to optimal use of technology for the improvement of writing skills in their educational level and for future professional use.

\section{References}

AbuSeileek, A., \&Abualsha'r, A. (2014).Using peer computing-mediated corrective feedback to support EFL learners' writing. Language Learning\& Technology 18 (1), 76-95. Retrieved from http://llt.msuedu/issues/february2014/abyseileekabualshar.pdf

Adas, D. \&Bakir, A. (2013).Writing difficulties and new solutions: blended learning as an approach to improve writing abilities.International Journal of Humanities and Social Science, 3(9), 254-266.

Albalawi, R. B. (2015). The effect of different teaching delivery method (Face to face, virtual and blended on intermediate students' academic achievement. West East Journal of Social Sciences, 1(4), 29-45.

Baker, M (2011). Three component of writing skills.Process and Politics, Writer vs. Reader.Retrieved from http://everypageispageone.com/2011/09/15/three-components-of-writing-skill.

Chappell, S. (2011).Utilizing the aesthetics of destabilization to read the public pedagogy in young people's community-based social justice artworks.Journal of Curriculum Theorizing, 27(3).

David, L., Keaton, R., Morris, R., Murphy, J.G., Stapley, I. (2008). A Space for Writing: Developmental Writing Instruction in a Technology-Enhanced Classroom.Creation of the Space: Form Follows Function.24, 15-26.

Gditawi, F., Noah, M., \& Abdul Ghani, Q. (2011). The relationship between motivation and learning reading and writing in sixth graders in the Hashemite Kingdom of Jordan.Journal of Islamic and Arabic Education, 3(1).13-28.

Douglas, K. H., Ayres, K. M., Langone, J., Bramlett, V. B. (2011). The effectiveness of electronic text and pictorial graphic organizers to improve comprehension related to functional skills. Journal of Special Education Technology, 26(1), 43-56.

Geluso, J. (2013). Phraseology and frequency of occurrence on the web: Native speakers' perceptions of Googleinformed second language writing. Computer Assisted Language Learning, 26(2), 144-157.

Godwin-Jones, R. (2009). Emerging technologies personal learning environments. Language Learning \& Technology 13(2), 3-9. Retrieved from http://llt.msu.edu/vol13num2/emerging.pdf Google Sites.(n.d.). Google sites overview. Retrieved from http://www.google.com/sites/overview.html 
Gregoriades, A., Pampaka, M., \&Michail, H. (2009).Assessing students' learning in misusing concept mapping.Journal of Information Systems Education, 20(4), 419-430.

He, L. (2015).On cultivation of learner autonomy in English writing in college.International Conference on Arts, Design and Contemporary Education (ICADCE 2015), 601-605. Retrieve from: https://pdfs.semanticscholar.org

Hussein, H. B. (2011). Attitudes of Saudi universities faculty members towards using learning management systems. TOJET: The Turkish Online Journal of Educational Technology (10)2, 40-44.

Kelley, M. J. (2008). The Impact of Weblogs on the Affective States and Academic Writing of

L2 Undergraduates (Unpublished doctoral dissertation), University of Virginia, United States.

Kelly, M. (2018). Lectures in Schools: Pros and Cons. Retrieved from https://www.thoughtco.com/lecture-pros-andcons

Liu, C. \& Long, F. (2014).The discussion of traditional teaching and multimedia teaching approach in college English teaching.International Conference on Management, Education and Social Science (ICMESS). 31-33. Retrieved from https://www.sciencedirect.com.

Martin, F. (2008).Blackboard as the learning management system of a computer literacy course.MERLOT J. online Learning and Teaching, 4(2), 138-145.

Nazzal, N. (2014). Modern vs traditional teaching methods. Retrieved from https://gulfnews.com/uae/education/modern-vs-traditional-teaching-methods

Panah, E., Yunus, M. M., \&Embi, M. A. (2013). Google-informed patter-hunting and pattern-defining: Implication for language pedagogy. Asian Social Science 9(3), 229-238. Retrieved from http://search.proquest.com/docview/1346873861?accountid=7305

Prakash, P. (2007). Psychological Foundation of Education.New Delhi: Kanishka Publishers.

Qian, X. (2010). A balanced approach to the teaching of intermediate-level writing

skills to EFL students. English Language Teaching. 3(2), 13-16.

Ramaswami, R. (2009). The prose and a few cons, too of electronic journaling. T.H.E. Journal 20-25,(11), 35.

Ridha, N. (2012). The Effect of EFL Learners' Mother Tongue on their Writings in English: An Error Analysis Study.Journal of the College of Arts. University of Basrah, 60, 22-45.

Sarfraz, S. (2011).Error analysis of the written English essays of Pakistani undergraduate students: A case study.Asian Transactions on Basic and Applied Sciences, 1(3), 29-50.

Santoso, A. (2010) Scaffolding an EFL (English as a foreign language) effective writing class in a hybrid learning community.Unpublished Doctor's Thesis, Queensland University of technology.

Sawalmeh, M.H. (2013). Error analysis of written English essays: the case of students of the preparatory year program in Saudi Arabia.English for Specific Purposes World, 40 (14), 1-17. Retrieved from http://www.espworld.info.

Scott, P., \&Mouza, C. (2007). The Impact of Professional Development On Teacher Learning,

Practice, And Leadership Skills: A Study on the Integration of Technology in the Teaching of Writing.J. Educational Computing Research, 37 (3), 229-266.

Stine, L. J. (2010). Teaching basic writing in a web-enhanced environment.Journal of Basic Writing 29(1), 33-55. Retrieved from http://search.proquest.com/docview/748819717?accountid=7305

Wilson, D., \& Allen, D. (2010). Success rates of online versus traditional college student. Retrieved from http://sdl.edu.sa

Writer Staff, (2011). 10 Big Problems With Lecture-Based Learning. Retrieved from https://www.onlineuniversities.com/10-Big-Problems-With-Lecture-Based-Learning

Zarei, A. A., \&Gahremani, K. (2010).On the relationship between learner autonomy and reading comprehension. Retrieved from http://www.ikiu.ac.ir/public-files/profiles/items/090ad_1424769045.pdf 